\title{
PERANAN PERGURUAN TINGGI DI SEMARANG DALAM PELESTARIAN WAYANG ORANG NGESTI PANDOWO
}

\author{
Dhanang Respati Puguh,* Mahendra Pudji Utama, Rabith Jihan Amaruli
}

\author{
Departemen Sejarah, Fakultas Ilmu Budaya, Univesitas Diponegoro \\ Semarang - Indonesia
}

*Alamat korespondensi: dhanang.respati@live.undip.ac.id

DOI: https://doi.org/10.14710/jscl.v4i2.25753

Diterima/Received: 4 October 2019; Direvisi/ Revised: 12 November 2019; Disetujui/ Accepted: 10 Desember 2019

\begin{abstract}
Ngesti Pandowo is a wayang orang group founded in Madiun, East Java on July 1, 1937. Since 1954, this community has been settled in Semarang and reached its heyday in the 1950-1970 and become the City's icon. In the late 1970s, Ngesti Pandowo suffered a continuing setback. It raised the concern and attention of a number of groups including the government, universities in Semarang, and the business parties to maintain its sustainability. This article is focused on the discussion of the efforts of the universities in Semarang to preserve Ngesti Pandowo. This article used historical methods, oral history, and literature study. The results show that universities in Semarang had played an important role in preserving Ngesti Pandowo through various activities, namely: art appreciation, management development, player support, and technology utilization.
\end{abstract}

Keywords: University; Wayang Orang; Ngesti Pandowo; Traditional Performing Art; Preservation.

\begin{abstract}
Abstrak
Ngesti Pandowo merupakan paguyuban wayang orang yang didirikan di Madiun, Jawa Timur pada 1 Juli 1937. Sejak 1954 paguyuban ini menetap di Semarang dan mencapai masa kejayaannya pada pada periode 1950-1970 serta telah menjadi icon Kota Semarang. Pada akhir dasawarsa 1970 Ngesti Pandowo mengalami kemunduran yang berkelanjutan. Hal ini memunculkan keprihatinan dan perhatian sejumlah kalangan antara lain pemerintah, perguruan tinggi di Semarang, dan dunia usaha untuk menjaga kelestariannya. Artikel ini difokuskan pada pembahasan tentang peranan perguruan tinggi di Semarang dalam upaya-upaya pelestarian Ngesti Pandowo. Artikel ini disusun dengan menggunakan metode sejarah, sejarah lisan, dan studi pustaka. Hasil penelitian menunjukkan bahwa perguruan tinggi di Semarang telah berperan dalam pelestarian Ngesti Pandowo melalui berbagai kegiatan, yaitu: apresiasi seni, pengembangan manajemen, dukungan pemain, dan pemanfaatan teknologi.
\end{abstract}

Kata Kunci: Perguruan Tinggi; Wayang Orang; Ngesti Pandowo; Pelestarian Seni Tradisi.

\section{PENDAHULUAN}

Lembaga pendidikan memiliki peranan penting dalam pelestarian seni pertunjukan tradisi Jawa. Kajian Puguh (2015) telah menunjukkan kontribusi lembaga-lembaga pendidikan formal di bidang seni dalam peningkatan kualitas esteti dan apresiasi masyarakat serta penyebarluasan seni pertunjukan tradisi Jawa Surakarta. Usaha yang sama dilakukan oleh Widyastutieningrum (2018) yang juga telah membahas tentang upaya pengembangan wayang orang Sriwedari yang dilakukan antara lain oleh Institut Seni Indonesia (ISI) Surakarta melalui pengemasan wayang orang sebagai seni wisata. Namun, tidak dapat dimungkiri, bahwa upaya semacam itu juga dilakukan oleh lembaga-lembaga pendidikan formal nonseni. Di Semarang, hal semacam itu 
telah dilakukan oleh beberapa perguruan tinggi. Namun demikian, peranan lembaga pendidikan nonseni dalam pengembangan seni pertunjukan tradisi Jawa, kurang mendapat perhatian. Padahal, di sebuah kota yang tidak memiliki lembaga pendidikan seni, perguruan tinggi di Semarang telah menjadi pilar pelestarian seni pertunjukan tradisi Jawa di tengah zaman yang berubah. Oleh karena itu, artikel ini berfokus pada peranan perguruan tinggi dalam pelestarian wayang orang Ngesti Pandowo, sebuah kelompok paguyuban seni pertunjukan tradisi Jawa yang telah menjadi ikon Kota Semarang.

Wayang orang Ngesti Pandowo didirikan oleh Ki Sastrosabdo di Madiun, Jawa Timur, pada 1 Juli 1937. Pada awalnya wayang orang panggung ini mengadakan pentas keliling di berbagai kota di Jawa Timur dan Jawa Tengah. Sejak 1954 paguyuban ini menetap di Kota Semarang. Wayang orang Ngesti Pandowo mencapai kejayaan pada dasawarsa 1950-1970. Pada masa itu Ngesti Pandowo memiliki dua orang seniman kreator yang mumpuni. Mereka adalah Ki Sastrosabdo yang menjadi pimpinan produksi, sutradara, dan pemeran tokoh Petruk; dan Ki Nartosabdo sebagai pimpinan karawitan yang produktif dalam menggarap musik pengiring dan mencipta lagu. Anak wayang paguyuban ini andal dalam antawacana, tembang, dan tari serta kreatif dalam mengembangkan trik panggung yang dikagumi oleh penonton, antara lain trik terbang yang lebih naturalistik dan trik beralih rupa (malihan). Ngesti Pandowo pernah beberapa kali diundang ke istana negara baik untuk pentas secara penuh maupun pentas fragmen Bambangan-Cakil. Suwarni dan Sutjipto Dihardjo bahkan menjadi pasangan penari Bambangan-Cakil favorit Presiden Sukarno. Pada 17 Agustus 1962 Ngesti Pandowo mendapat anugerah seni Piagam "Wijayakusuma" dari Pemerintah Republik Indonesia. Koesni, salah satu penari Ngesti Pandowo, pada 1964-1965 juga mendapatkan kesempatan untuk mengikuti misi kebudayaan ke Kamboja, Filipina, Korea, Cina, dan Jepang (Puguh, Amaruli, dan Utama, 2017). Pada 1970 Ngesti Pandowo mendapat kehormatan untuk melakukan rekaman piringan hitam dengan lakon Anoman Duta dan Gendreh Kemasan di P.N. Lokananta, dan dengan lakon Kresna Kembang di
Indah Record. Pada tahun itu anak wayang Ngesti Pandowo juga dilibatkan dalam produksi rekaman kaset di P.N.Lokananta dengan cerita Keyong Mas dan Andhe-andhe Lumut, yang merupakan kerja sama dengan Paguyuban Karawitan Condhong Raos pimpinan Ki Nartosabdo (Yampolsky, 1987: 82; Puguh, Amaruli, dan Utama, 2017: 17). Dengan berbagai capaiannya itu, wayang orang Ngesti Pandowo pada masa kejayaannya menjadi wayang orang panggung terbaik di Kota Semarang (Panitia Pekan Pameran Ekonomi dan Kebudayaan Kodya Semarang, 1968: 84). Ngesti Pandowo juga merupakan paguyuban wayang orang panggung yang besar dan terkenal serta mampu mengemas pertunjukan wayang orang yang bermutu tinggi. Di Jawa Tengah hanya ada dua paguyuban wayang orang panggung yang memenuhi kriteria itu, yaitu Sriwedari di Surakarta dan Ngesti Pandowo di Semarang (Koentjaraningrat, 1984: 308).

Mengikuti pendapat James R. Brandon, wayang orang Ngesti Pandowo merupakan commercial support art, sehingga kelangsungan hidupnya sangat dipengaruhi oleh hasil penjualan tiket. Pada masa kejayaannya, jumlah penonton Ngesti Pandowo mencapai rata-rata 1.000 orang pada setiap pentas. Sebagai contoh, pada 1964 ketika bermain selama dua bulan di Yogyakarta atas permintaan sebuah panitia dengan sponsor lokal, tobong yang didirikan di alun-alun utara Yogyakarta dengan kapasitas 1400 tempat duduk untuk pertunjukan Ngesti Pandowo selalu terisi penuh (Brandon, 2003: 257). Namun, sejak akhir 1970-an jumlah penontonnya terus menurun, sehingga kondisi keuangan paguyuban ini menjadi goyah. Pada 1982 Ngesti Pandowo bahkan harus menjual gamelannya demi menyambung hidup anggotanya (Suara Merdeka, 6 Oktober 1982). Kondisi ini telah menimbulkan keprihatinan bagi banyak pihak. Para seniman tradisi dan organisasi seni pertunjukan komersial dari Jakarta, Yogyakarta, dan berbagai kota di Jawa Tengah telah menunjukkan dukungan mereka melalui pentas bersama untuk menggalang dana bagi Ngesti Pandowo. Pemerintah Kota Semarang dan Provinsi Jawa Tengah serta kalangan dunia usaha di Kota Semarang juga telah memberi bantuan pendanaan dengan harapan agar wayang orang panggung itu dapat terus berkiprah dan kembali 
diminati oleh penontonnya (Puguh, Amaruli, dan Utama, 2017; Puguh dan Utama, 2018). Akan tetapi, bantuan-bantuan pendanaan itu rupanya belum mampu mengatasi kesulitan Ngesti Pandowo. Sampai dengan awal tahun 2000 jumlah penontonnya rata-rata hanya mencapai 30 orang pada setiap pentas. Mereka kebanyakan berasal dari Kota Semarang dan sekitarnya (Rinardi, Puguh, dan Maziyah, 2002; Rahardjo, Sanjaya, dan Untari, 2018).

Menurut Kayam (1982), bantuan pendanaan memang sangat diperlukan oleh Ngesti Pandowo. Namun, ia menegaskan bahwa bantuan itu tidak akan mengatasi kesulitan Ngesti Pandowo karena penyebab utama kemundurannya adalah tidak adanya seniman kreator yang mampu mengemas wayang orang yang bermutu dan penuh spectacle seperti pada masa kejayaannya. Sepeninggal Ki Sastrosabdo pada 1966 dan Ki Nartosabdo pada 1985, Ngesti Pandowo memang tidak memiliki seniman kreator yang sekaliber dengan kedua tokoh itu. Di sisi lain, Kayam (2000) juga menyoroti peranan lembaga-lembaga kebudayaan seperti taman budaya, dewan kesenian daerah atau dewan kebudayaan daerah. Ia menganggap bahwa lembaga-lembaga kebudayaan itu tidak memiliki orientasi dan komitmen yang jelas terhadap pengembangan seni tradisi dan budaya lokal pada umumnya.

Di tengah-tengah situasi itu, upaya mempertahankan dan mengembangkan seni pertunjukan tradisi Jawa diperlihatkan oleh lembaga-lembaga pendidikan formal. Yampolsky (2001) bahkan menyebut pendidikan formal sebagai bidang tunggal yang paling dapat diharapkan untuk membantu mempertahankan keberadaan seni tradisi. Dalam beberapa studi telah ditunjukkan pula tentang peranan lembaga pendidikan formal dalam pengembangan seni tradisi. Dalam konteks seni pertunjukan Jawa, upaya itu dilakukan bukan hanya oleh lembagalembaga pendidikan formal di Indonesia, tetapi juga di mancanegara. Di Amerika Serikat, misalnya, seni pertunjukan Jawa khususnya karawitan telah dijadikan mata kuliah di beberapa universitas. Dari universitas-universitas itu muncul kelompok-kelompok karawitan Jawa dan pentaspentas seni pertunjukan Jawa secara rutin baik di lingkungan kampus maupun gedung pertunjukan di luar kampus (lihat, antara lain: Sutton, 1985; Susilo, 1985; Sumarsam, 2018; Puguh dan Susilowati, 2018). Bahkan, seni karawitan Jawa juga dapat berkembang di Jepang. Ini merupakan suatu yang menarik karena masyarakat Jepang dikenal sangat membanggakan kebudayaan mereka sendiri (Surjodiningrat, 1985).

Persoalan yang dihadapi oleh paguyuban wayang orang Ngesti Pandowo ini sebetulnya cukup kompleks. Selain tidak adanya seniman kreator seperti yang telah dikemukakan oleh Kayam di atas, ada sejumlah faktor internal yang memengaruhi kemunduran wayang orang Ngesti Pandowo, yaitu regenerasi pemain yang tidak berjalan secara baik, manajemen organisasi seni pertunjukan yang tidak lagi relevan dengan kondisi zaman, dan kemasan pertunjukan yang kurang inovatif. Secara eksternal, kemunduran itu juga dapat dihubungkan dengan perubahan selera masyarakat, rendahnya apresiasi masyarakat terhadap seni tradisi Jawa, dan perkembangan teknologi media rekam serta berbagai bentuk hiburan baru di Kota Semarang (Puguh, Amaruli, dan Utama, 2017). Oleh karena itu, harus disampaikan bahwa upaya kalangan perguruan tinggi di Kota Semarang dalam pengembangan wayang orang Ngesti Pandowo hanya menjangkau sebagian aspek dalam kehidupan seni pertunjukan tradisi, yaitu peningkatan apresiasi masyarakat, perbaikan manajemen organisasi, dukungan pemain, dan peningkatan daya tarik pertunjukan. Biarpun demikian upaya yang telah mereka lakukan itu layak untuk mendapatkan perhatian; tidak saja karena mereka bukan merupakan perguruan tinggi seni, tetapi juga karena upaya itu dapat membantu mengatasi sebagian persoalan dasar yang dihadapi oleh wayang orang Ngesti Pandowo.

\section{METODE}

Artikel ini mengaplikasikan metode sejarah, yaitu seperangkat prinsip yang berisi kaidah-kaidah sistematis untuk menemukan, menguji, dan menganalisis secara kritis rekaman dan peninggalan masa lampau dan kemudian mengonstruksinya secara imajinatif menjadi suatu cerita sejarah (Garraghan, 1959: 33). Metode ini 
terdiri atas empat tahap yaitu: heuristik, kritik, interpretasi, dan historiografi.

Heuristik dilakukan dengan menelusuri arsip, foto, dan surat kabar khususnya Kompas dan Suara Merdeka. Penelusuran arsip dan foto Ngesti Pandowo dilakukan di Sekretariat Ngesti Pandowo serta beberapa koleksi pribadi pengurus dan peneliti. Pengumpulan sumber juga dilakukan dengan menggunakan metode wawancara sejarah lisan, yaitu suatu usaha untuk mengumpulkan data dan informasi tentang masa lampau dengan melakukan wawancara dengan pelaku sejarah atau saksi mata (Thompson, 1978). Kegiatan terpenting yang langsung berkaitan dengan pengumpulan sejarah lisan adalah wawancara, penyalinan, dan penyuntingan (Davis et al., 1977). Pengumpulan sumber juga dilakukan dengan menggunakan metode studi pustaka. Studi pustaka dilakukan di Perpustakaan Departemen Sejarah Fakultas Ilmu Budaya dan Unit Pelaksana Teknis (UPT) Perpustakaan Universitas Diponegoro, serta Perpustakaan Wilayah Jawa Tengah di Semarang.

Untuk mengungkapkan peranan perguruan tinggi di Semarang dalam pelestarian Wayang Orang Ngesti Pandowo, digunakan pula metode observasi dan wawancara individual mendalam. Observasi dilakukan dengan mengadakan pengamatan terhadap pementasan kerja sama Ngesti Pandowo dengan beberapa perguruan tinggi di Semarang, baik yang diselenggarakan di dalam maupun di luar tempat pentas rutinnya, yaitu Gedung Ki Nartosabdo di Taman Budaya Raden Saleh Semarang. Pada tahap ini, penelitian dilakukan melalui pencatatan terhadap hal-hal yang diperlukan dan penting. Dalam observasi digunakan alat bantu berupa kamera foto, alat perekam suara, dan handycam untuk mengabadikan pementasan itu, sehingga akan memudahkan peneliti mengetahui aspek estetis pertunjukan. Alat-alat rekam tersebut berguna untuk merekam data kualitatif yang dihasilkan dari proses komunikasi nonverbal. Rekaman-rekaman itu kemudian dijadikan objek pengamatan dan untuk dianalisis (Soedarsono, 1999: 39 dan 148). Metode pengamatan semacam ini disebut observasi ex post facto, karena peristiwa yang diamati telah berlangsung (Sevilla et al., 1993: 24). Wawancara dilakukan terhadap tokoh-tokoh "penggerak" seni pertunjukan di beberapa perguruan tinggi di Semarang, yaitu di Universitas Diponegoro, Universitas Negeri Semarang, Universitas 17 Agustus 1945 Semarang, dan Universitas Katolik Soegijapranata.

Sumber-sumber yang telah dikumpulkan selanjutnya dikritik, sehingga diperoleh fakta-fakta sejarah yang kredibel. Fakta-fakta sejarah ini kemudian diinterpretasi berdasar kronologi dan hubungan sebab-akibat, dan selanjutnya dikonstruksi menjadi kisah sejarah (history as written).

\section{PENINGKATAN APRESIASI SENI: WAYANG MASUK KAMPUS}

Pada dasawarsa 1980, dalam kaitan dengan mata kuliah Masyarakat dan Kesenian Indonesia, Fakultas Sastra Universitas Diponegoro mewajibkan kepada mahasiswa yang menempuh mata kuliah itu untuk menonton wayang orang Ngesti Pandowo. Pemilihan seni pertunjukan ini didasari oleh pertimbangan teoretis dan praktis. Dalam mata kuliah Masyarakat dan Kesenian Indonesia dipelajari dua konsep penting dalam kaitan dengan kategori seni yang tumbuh dan berkembang di Indonesia, yaitu seni tradisi dan kitsch. Pemilihan Ngesti Pandowo dipandang dapat mewakili kedua kategori itu. Di satu sisi, wayang orang merupakan salah satu bentuk seni tradisi, di sisi lain Ngesti Pandowo yang menyajikan wayang orang dalam pertunjukannya mewakili sebuah teater kitsch yang pernah mengalami masa kejayaan di Semarang. Dengan menonton wayang orang Ngesti Pandowo mahasiswa sekaligus dapat mengetahui salah satu khasanah seni tradisi yang telah dikembangkan menjadi kitsch, yang oleh Kayam (1991: 13) didefinisikan sebagai seni kemasan yang dipertunjukkan bagi khalayak kota. Di pihak lain, kehadiran para penonton mahasiswa dalam jumlah yang cukup banyak ini diharapkan dapat membantu mengatasi penurunan jumlah penonton. Upaya untuk meningkatkan apresiasi terhadap wayang orang Ngesti Pandowo ini juga telah menginspirasi Heni Sulistyo Mumpuni, mahasiswa Jurusan Sejarah Universitas Diponegoro, untuk menulis skripsi dengan judul 
"Pertumbuhan Perkumpulan Kesenian Ngesti Pandowo Semarang Tahun 1937-1983” (1986).

Pada awal dasawarsa 1990, ketika Fakultas

Sastra Universitas Diponegoro di bawah kepemimpinan Prof. Dr. Istiati Soetomo, dekan yang sangat mencintai seni pertunjukan tradisi Jawa ini membuat kebijakan yang berbeda dari dekan pada masa sebelumnya. Pada setiap tahun ajaran baru diadakan kegiatan studium generale dengan menggelar seni pertunjukan tradisi Jawa antara lain wayang kulit purwa dan wayang orang sebagai manifestasi dari program Wayang Masuk Kampus. Keesokan harinya diadakan acara diskusi dengan melibatkan para dosen dan mahasiswa baik sebagai pembicara, moderator maupun peserta. Menurut ingatan penulis utama, paling sedikit telah dipergelarkan tiga kali pergelaran wayang kulit purwa dengan format pakeliran ringkas masing-masing oleh dhalang Ki Mujoko Djoko Rahardjo dari Klaten dengan lakon BaladewaBalarama, Prof. Dr. Wisnu Wardana dari Institut Keguruan dan Ilmu Pendidikan Negeri (sekarang Universitas Negeri) Yogyakarta dengan lakon Janaka: The Super Hero, dan Ki Purbo Asmoro, S. Kar. dari Sekolah Tinggi Seni Indonesia (sekarang Institut Seni Indonesia) Surakarta dengan lakon Kresna Duta. Dalam kaitan dengan studium generale, Fakultas Sastra Universitas Diponegoro juga pernah bekerja sama dengan Panitia Tetap Wayang Provinsi Jawa Tengah untuk menyelenggarakan pergelaran wayang kulit purwa oleh dhalang kondhang Ki Manteb Soedharsono di Auditorium Imam Bardjo dengan lakon Setiaki Setiaki. Selain itu, juga pernah ditampilkan satu kali pertunjukan wayang orang dengan lakon Kresna Duta yang disajikan oleh perkumpulan wayang orang Ngesti Pandowo.

Pergelaran seni pertunjukan Jawa di kampus Fakultas Sastra Universitas Diponegoro bukan tanpa tujuan. Pergelaran itu antara lain didasari oleh adanya keprihatinan dari pimpinan fakultas yang mewakili generasi tua terhadap eksistensi seni pertunjukan tradisi Jawa yang semakin marjinal dalam kehidupan kebudayaan yang antara lain ditandai oleh sikap generasi muda yang tidak apresiatif terhadap seni pertunjukan wayang. Penyelenggaraan studium generale itu bertujuan untuk meningkatkan apresiasi seni mahasiswa yang mewakili generasi muda terhadap seni pertunjukan wayang. Pemilihan Ngesti Pandowo untuk tampil di panggung terbuka Fakultas Sastra juga dilandasi oleh kondisi internal Ngesti Pandowo. Pada saat itu, Ngesti Pandowo semakin terpuruk karena sepi penonton. Kesempatan yang diberikan kepada mereka merupakan salah satu bentuk kepedulian masyarakat kampus agar Ngesti Pandowo dapat mempertahankan eksistensinya, mengingat Ngesti Pandowo pernah menjadi ikon Kota Semarang.

Pada sekitar tiga dasawarsa kemudian (2017) Universitas Diponegoro kembali memberikan perhatian khusus pada perkumpulan wayang orang Ngesti Pandowo melalui pergelaran wayang orang bertajuk "Wayang Specta 60". Sebutan "Wayang Specta 60" digunakan karena pentas wayang orang itu dilaksanakan dalam rangka Dies Natalis Universitas Diponegoro yang ke- 60 dan didukung oleh 60 orang guru besar dan pejabat perguruan tinggi tersebut. Para seniman Ngesti Pandowo dan para guru besar dan pejabat Universitas Diponegoro yang secara keseluruhan berjumlah 100 orang terlibat dalam produksi wayang orang spektakuler itu. Rektor Universitas Diponegoro Prof. Dr. Yos Johan Utama, S.H., M. Hum. dalam sambutannya menandaskan, bahwa Universitas Diponegoro yang sedang membangun kegiatan riset dan publikasi ilmiah bagi kemajuan institusinya, tidak melupakan kedudukannya sebagai perguruan tinggi yang juga mengemban misi untuk memajukan kebudayaan Indonesia, termasuk seni pertunjukan tradisi Jawa. Melalui pentas "Wayang Specta 60", Universitas Diponegoro telah berperan dalam upaya-upaya untuk melestarikan seni pertunjukan tradisi Jawa dan menjaga eksistensi perkumpulan wayang orang legendaris Semarang, Ngesti Pandowo.

\section{PENGEMBANGAN MANAJEMEN}

Perhatian perguruan tinggi terhadap aspek manajemen Ngesti Pandowo diawali oleh adanya sebuah studi yang dilakukan oleh Tim Peneliti Jurusan Sejarah Fakultas Sastra Universitas Diponegoro melalui penelitian yang berjudul "Perkumpulan Wayang Orang Ngesti Pandowo (1937-2001): Studi tentang Manajemen Seni Pertunjukan” (Rinardi, Puguh, Maziyah, 2002). Penelitian ini menyoroti tentang manajemen seni 
pertunjukan yang diterapkan oleh Ngesti Pandowo berdasar perspektif sejarah yang mencakup periode 1937-2001. Melalui penelitian ini, walaupun belum komprehensif, telah diperoleh gambaran tentang manajemen seni pertunjukan yang diterapkan oleh Ngesti Pandowo. Sebagai penelitian dengan perspektif sejarah, hasil penelitian ini dapat dijadikan sebagai dasar berpijak untuk melakukan pembenahan manajemen Ngesti Pandowo.

Sekitar lima tahun kemudian, tepatnya pada 2007, dibentuk Dewan Pembina Ngesti Pandowo. Keberadaan dewan pembina ini didasari oleh adanya keprihatinan terhadap kondisi dan eksistensi Ngesti Pandowo yang semakin mengalami kemunduran. Dewan pembina ini terdiri atas orang-orang yang memiliki kepedulian untuk menyelamatkan keberadaan Ngesti Pandowo, yang sebagian berasal dari kalangan perguruan tinggi di Semarang, yaitu: Prof. Dr. dr. Edi Dharmana, M.Sc., Sp. Park. (Universitas Diponegoro), Prof. Dr. Soetomo, W.E., M. Pd. (Sekolah Tinggi Ilmu Ekonomi Pariwisata), dan Drs. Dhanang Respati Puguh, M. Hum. (Universitas Diponegoro). Di bawah kepemimpinan Prof. Dr. dr. Edi Dharmana, M.Sc., Sp. Park. Dewan Pembina melakukan upaya-upaya untuk melestarikan Ngesti Pandowo. Di bawah kepemimpinannya Dewan Pembina dan Ngesti Pandowo mengadakan pementasan-pementasan dan kerja sama dengan pihak lain untuk melestarikan keberadaan Ngesti Pandowo (Puguh, Amaruli, Utama, 2017: 152). Keberadaan Dewan Pembina yang sebagian berasal dari kalangan perguruan tinggi memiliki peranan yang cukup signifikan bagi kelestarian Ngesti Pandowo.

Berdasar penelitian yang telah dilakukan pada 2002, Tim Peneliti Departemen Sejarah Fakultas Ilmu Budaya Universitas Diponegoro kemudian mengembangkan penelitian itu dengan penelitian yang lebih komprehensif dan mendalam dengan judul "Model Pengembangan Manajemen Seni Pertunjukan Tradisi untuk Mengembangkan Wayang Orang Ngesti Pandowo guna Mendukung Pariwisata Budaya di Kota Semarang” (2016). Penelitian Tahun I difokuskan pada aspek historis Ngesti Pandowo sejak pendiriannya sampai dengan masa kemundurannya sampai dengan 2015. Dari penelitian itu telah berhasil diungkap faktor-faktor yang membawa Ngesti Pandowo mencapai puncak kejayaannya pada periode 19501970 dan kemundurannya sejak akhir dasawarsa 1970. Faktor-faktor yang menyebabkan kejayaan Ngesti Pandowo adalah dukungan Pemerintah Kota Semarang dan penerapan model manejemen yang tepat. Setelah menetap di Kota Semarang sejak 1954, Ngesti Pandowo mendapat banyak perhatian dari pemerintah daerah khususnya Pemerintah Kota Semarang. Hal ini membuat Ngesti Pandawa unik, karena merupakan kelompok commercial support namun mendapat dukungan dari pemerintah termasuk dalam bentuk bantuan pendanaan. Di samping itu, Ngesti Pandowo menerapkan model manajemen yang sesuai dengan karakteristiknya sebagai sebuah paguyuban dan kondisi zaman pada kurun itu. Dalam manajemen organisasi, Ngesti Pandowo dipimpin oleh Sastrosabdo yang menerapkan dengan baik gaya kepemimpinan ambapaberdasar prinsip asih, asah, dan asuh yang mampu menjadikan seluruh anggota Ngesti Pandowo memiliki komitmen dan dedikasi yang tinggi terhadap paguyuban. Dalam mengelola organisasi, Sastrosabdo dibantu oleh bendahara yang andal yaitu Sastrosudirdjo. Dilihat dari aspek manajemen produksi, Ngesti Pandowo dikelola oleh orang-orang yang mumpuni. Sastrosabdo merupakan sosok yang sangat berwibawa bagi warga paguyuban ini karena kemampuannya yang mumpuni dalam mengelola seni pertunjukan panggung. Ia juga memiliki kepekaan dan kecermataan yang tinggi dalam melihat potensi warga paguyuban dan menempatkannya untuk mengemban tugas yang sesuai dengan keahlian mereka, seperti yang ditunjukkan dengan mengangkat Koesni sebagai sutradara dan Nartosabdo sebagai pemimpin karawitan. Sementara itu, dilihat dari aspek manajemen pemasaran, Ngesti Pandowo tidak mempunyai bagian khusus yang menangani bidang pemasaran. Untuk memasarkan produknya, Ngesti Pandowo menggunakan papan iklan, iklan di media massa cetak dan elektronik, spanduk, pamflet, dan pengumuman secara berkeliling dengan menggunakan kendaraan yang dilengkapi dengan pengeras suara. Walaupun masih terlihat sederhana, namun untuk ukuran pada saat itu 
manajemen pemasaran semacam itu sudah dapat memenuhi kebutuhan Ngesti Pandowo.

Pamor Ngesti Pandowo sebagai teater kitsch mulai surut sejak akhir dasawarsa 1970. Indikasi paling jelas adalah penurunan jumlah penonton yang terus berlangsung hingga saat ini. Kemunduran paguyuban ini dapat dihubungkan dengan perkembangan teknologi yang dikuti dengan berkembangnya seni media rekam, selain menjamurnya tempat-tempat hiburan di Kota Semarang khususnya bioskop. Akan tetapi, persoalan terbesar yang menyebabkan kemunduran itu berasal dari dalam paguyuban itu sendiri. Sepeninggal tokoh-tokoh yang telah membawa paguyuban ini ke masa kejayaan, Ngesti Pandowo tidak lagi memiliki tokoh-tokoh seniman kreatif dan inovatif serta menjadi panutan. Regenerasi yang tidak berjalan secara baik juga mengakibatkan minimnya pemain muda. Sebagian dari mereka bahkan kehilangan rasa bangga sebagai anak wayang Ngesti Pandowo. Semua itu telah mengakibatkan penurunan kualitas pergelaran dan daya tarik Ngesti Pandowo sebagai sebuah teater kitsch yang dituntut untuk menampilkan seni pertunjukan gemerlap dengan trik-trik panggung yang memikat penonton (Puguh, Amaruli, Utama, 2016).

Penelitian Tahun II difokuskan pada aspek manajemen seni pertunjukan Ngesti Pandowo yang mencakup manajemen organisasi, manajemen produksi, dan manajemen pemasaran. Pembahasan aspek manajemen organisasi, produksi, dan pemasaran ditekankan pada hal-hal yang bersifat positif yang telah mengantarkan Ngesti Pandowo mencapai masa kejayaan, yaitu kepemimpinan yang bersifat kebapakan dan didasarkan pada prinsip asih, asah, dan asuh terbukti mampu menjadikan anggota Ngesti Pandowo memiliki komitmen untuk mengembangkan organisasinya. Manajemen organisasi semacam itu berpengaruh positif terhadap manajemen produksi dan pemasaran. Seluruh eksponen Ngesti Pandowo memiliki kesadaran untuk menjalankan fungsinya masingmasing, sehingga berhasil mencapai masa kejayaannya. Karaktersitik manajemen seni pertunjukan yang bersifat positif ini dijadikan dasar untuk menyusun model manajemen seni pertunjukan untuk Ngesti Pandowo (Puguh, Amaruli, Utama, 2017).

Berdasar hasil penelitian tahun I dan II telah dibuat model pengembangan manajemen seni pertunjukan seni tradisi yang dipandang cocok untuk Ngesti Pandowo. Model manajemen seni pertunjukan seni tradisi yang dikembangkan untuk Ngesti Pandowo didasarkan pada manajemen yang pernah diterapkan pada Ngesti Pandowo pada masa kejayaannya. Model manajemen seni pertunjukan tradisi itu kemudian disosialisasikan kepada anggota Ngesti Pandowo melalui sarasehan dan perbincangan secara informal dalam berbagai kesempatan. Tim peneliti juga melakukan koordinasi dengan pimpinan Ngesti Pandowo untuk membicarakan rencana pergelaran sebagai tindak lanjut dari sosialisasi model manajemen seni pertunjukan wayang orang yang mencakup waktu dan tempat pergelaran, lakon yang disajikan, konsep-konsep garapan seni pertunjukan sebagai seni wisata, dan tuntutan untuk mengadakan persiapan dan pelatihan, dan pendanaan. Beberapa hari kemudian dilakukan rapat internal Ngesti Pandowo yang melibatkan tim produksi yang memiliki fungsi menjalankan tugas manajemen organisasi, produksi, dan pemesaran. Berdasar rapat internal itu, akhirnya disepakati untuk menyajikan lakon Sembadra Larung dengan pertimbangan lakon ini merupakan lakon rame alias banyak adegan perangnya, sehingga menarik perhatian penonton. Pergelaran dengan lakon itu juga lebih memungkinkan untuk menggarap adegan perang dengan ragam gerak tari yang lebih bervariasi. Selain itu, Ngesti Pandowo dengan properti yang dimilikinya mampu mendukung beberapa adegan dengan dekorasi panggung yang menarik perhatian penonton, misalnya dekorasi untuk adegan di taman dan di bengawan (sungai) ketika Dewi Sembadra dihanyutkan di atas sebuah perahu.

Pihak Ngesti Pandowo menyiapkan sinopsis dan narasi pendek berbahasa berbahasa Indonesia yang ditampilkan melalui LCD pada saat pementasan sesuai dengan adegannya. Untuk kepentingan pelatihan dan pementasan telah disusun balungan lakon atau keliran berbahasa Jawa yang berisi garis besar delapan adegan yang disajikan, yaitu Wana Minangsraya, Taman Madukara, Kesatrian Madukara, Bengawan, Margi, 
Bengawan, Margi, dan Wana Minangsraya. Sutradara dan asisten sutradara telah menyusun para pemain untuk pementasan Sembadra Larung. Ngesti Pandowo juga membuat electronic flyer untuk mempromosikan pergelaran ini yang diunggah melalui facebook dan WhatsApp. Promosi dilakukan pula melalui Radio Republik Indonesia Semarang.

Berdasar rencana yang telah disusun itu kemudian dilakukan pelatihan. Sutradara dan asistennya membagikan peran dan menjelaskan urutan adegan dan pokok-pokok pembicaraan dalam setiap adegan kepada para pemain. Sutradara berkoordinasi dengan pimpinan karawitan untuk mempersiapkan gendhing yang akan digunakan untuk mengiringi setiap adegan, dan dengan tim tata panggung dan tata cahaya untuk mempersiapkan dekorasi, peralatan, dan pencahayaan yang ditampilkan pada setiap adegan. Tidak semua adegan ditampilkan secara utuh dalam pelatihan, melainkan terbatas pada adeganadegan yang dianggap penting dan memerlukan persiapan khusus, yaitu adegan Wana Minangsraya, Taman Madukara, Gara-gara, dan Perang. Pelatihan adegan-adegan itu diiringi dengan gamelan secara live. Pementasan Sembadra Larung digelar pada Sabtu 9 Februari 2019 dari pukul 20.00 sampai dengan 22.30 (Puguh, Amaruli, Utama, 2018). Melalui penelitian multitahun itu tampak bahwa Departemen Sejarah Fakultas Ilmu Budaya Universitas Diponegoro telah ikut berperan dalam pelestarian wayang orang Ngesti Pandowo.

\section{DUKUNGAN PEMAIN}

Regenerasi pemain khususnya pemain wanita merupakan salah satu persoalan yang dihadapi oleh Ngesti Pandowo. Sejumlah sivitas akademika perguruan tinggi baik atas inisiatif sendiri maupun institusional berperan serta dalam penyelesaian persoalan yang dihadapi oleh Ngesti Pandowo. Mereka sering terlibat dalam pementasan baik rutin maupun insidental yang digelar oleh Ngesti Pandowo. Adapun para pendukung dari perguruan tinggi itu antara lain Prof. Dr. dr. Edi Dharmana, M.Sc., Sp. Park., Ir. Aris Krisdianto, M.T., dan dr. Meita Adiaria, M.S. Med. Berikut ini adalah profil dan kiprah mereka dalam perkumpulan wayang orang Ngesti Pandowo.

Perkenalan dan keterlibatan Prof. Dr. dr. Edi Dharmana, M.Sc., Sp. Park. dengan Ngesti Pandowo telah berlangsung lama. Edi Dharmana tidak berasal dari keluarga seniman, namun kedua orang tuanya sangat mencintai seni tradisi Jawa. Kecintaan kedua orang tuanya terhadap seni tradisi Jawa telah mempertemukan Edi Dharmana dengan para seniman generasi pertama Ngesti Pandowo, karena ia harus belajar menari Jawa pertama kali kepada Nartosabdo yang saat itu menjadi pengrawit Ngesti Pandowo. Ia juga belajar menari Cakil kepada Sutjipto Dihardjo, anggota Ngesti Pandowo yang karena kemampuan dan keterampilannya dalam menampilkan tarian Cakil telah mengantarkan dirinya sering pentas di istana negara untuk menjamu para tamu negara pada masa pemerintahan Sukarno. Selain belajar menari pada seniman Ngesti Pandowo, Edi Dharmana pernah belajar menari kepada S. Maridi dari Surakarta (Gambar 1). Dari ketrampilan menari ini sejak Sekolah Dasar sampai dengan Sekolah Menengah Atas ia sering menari untuk acara resepsi perkawinan.

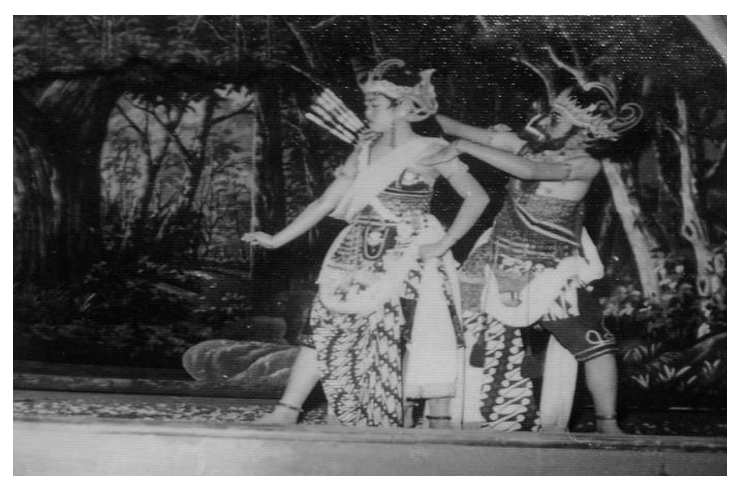

Gambar 1. Edi Dharmana tampil sebagai Cakil dalam pergelaran wayang orang Ngesti Pandowo pada 1962 (Sumber: Dokumentasi Pribadi Prof. Dr. dr. Edi Dharmana, M. Sc., Sp. Park.)

Oleh karena memiliki kemampuan menari, ketika masih duduk di bangku Sekolah Menengah Pertama melalui kebaikan budi Wali Kota Semarang Hadi Subeno ia pernah pentas di Ngesti Pandowo bersama Sastrosabdo. Ia juga pernah terlibat dalam pentas Ngesti Pandowo dengan lakon Gathutkaca Krama. Dalam pementasan itu tokoh Gathutkaca diperankan oleh Dhe Gus, putra Hadi Subeno. Ayahnya yang memiliki 
perkumpulan wayang yang anggotanya para tentara Urusan Moril juga pernah menyelenggarakan pentas kolaborasi bersama Ngesti Pandowo dengan melibatkan dirinya (Gambar 2).



Gambar 2. Prof. Dr. dr. Edi Dharmana, M.Sc., Sp. Park. sedang memerankan Antasena dalam pergelaran wayang orang Ngesti Pandowo dengan cerita Sembadra Larung di Gedung Ki Nartosabdo Taman Budaya Raden Saleh Semarang pada 9 Februari 2019 (Sumber: Dokumentasi Peneliti).

Perhatian Edi Dharmana terhadap Ngesti Pandowo tumbuh kembali setelah ia menjadi dokter. Perhatiannya menjadi semakin besar ketika ia menjabat sebagai Wakil Dekan IV Bidang Kerja Sama Fakultas Kedokteran Universitas Diponegoro. Ketika menjadi Wakil Dekan IV, ia membentuk grup tari dengan pelatih Kusleni dari Ngesti Pandowo yang saat itu telah berkerja sebagai pegawai Pemerintah Provinsi Jawa Tengah. Kelompok seni ini memfokuskan pelatihannya pada bidang tari dan kadang-kadang wayang orang. Pembinaan kepada para mahasiswa Fakultas Kedokteran ini bukan tanpa tujuan strategis. Para mahasiswa yang bisa menari dapat membantu pentas Ngesti Pandowo. Ketika menjadi dokter diharapkan mereka memiliki perhatian pada kebudayaan Jawa. Mereka menjadi dokter nasionalis dan cinta Negara Kesatuan Republik Indonesia melalui seni tradisi Jawa. Selain itu, pembentukan kelompok seni ini juga dimaksudkan agar kelak ketika sudah lulus menjadi dokter, mereka memiliki kepedulian kepada seni tradisi khususnya Ngesti Pandowo. Artinya, melalui jaringan alumi Fakultas Kedokteran Universitas Diponegoro, para dokter dapat membantu pendanaan untuk Ngesti Pandowo, paling tidak dengan membeli karcis setiap mengadakan pertunjukan-pertunjukan khusus.
Kelompok seni Fakultas Kedokteran Universitas Diponegoro juga pernah mengadakan pentas kolaborasi dengan Ngesti Pandowo dengan lakon Semar Kuning dan Kilat Buwana. Pelatihan seni tradisi Jawa, khususnya tari bagi mahasiswa anggota Unit Kegiatan Mahasiswa Kesenian Jawa masih berlangsung sampai sekarang dengan pelatih Maya yang juga anggota Ngesti Pandowo.

Setelah tidak lagi menjabat sebagai Wakil Dekan IV Fakultas Kedokteran Universitas Diponegoro, Prof. Dr. dr. Edi Dharmana, M.Sc., Sp.Park., tetap berkiprah dalam pengembangan Ngesti Pandowo. Ia memberikan kesaksian bahwa ternyata tidak mudah mengembangkan Ngesti Pandowo. Berbagai cara telah dilakukannya antara lain dengan penggalangan dana. Akan tetapi, ada pribadi yang kurang bertanggung jawab, sehingga membuat nama Ngesti Pandowo menjadi kurang baik di mata para penyandang dana. Dukungan dan kecintaan Prof. Dr. dr. Edi Dharmana, M.Sc., Sp.Park., terhadap Ngesti Pandowo tidak perlu diragukan lagi, karena ia sering kali harus meninggalkan praktik dokter untuk hadir dalam latihan dan pentas membantu Ngesti Pandowo. Menari baginya telah menjadi semacam obat yang dapat digunakan untuk mengobati dirinya sendiri ketika merasa kurang sehat (Wawancara dengan Prof. Dr. dr. Edi Dharmana, M.Sc., Sp. Park., 17 Mei 2019). Berdasar pengamatan penulis, selama tiga tahun terakhir ia sering membantu pentas Ngesti Pandowo dengan berperan antara lain sebagai Gathutkaca, Antasena, Bisma, dan Rahwana. Dari peran-peran yang dimainkan tampaknya ia sangat senang apabila memerankan tokoh Gathutkaca. Untuk memerankan tokohtokoh itu dengan senang hati ia membuat kostum wayang untuk dirinya sendiri.

Selain Prof. Dr. dr. Edi Dharmana, M. Sc., Sp. Park., sosok dari kalangan perguruan tinggi yang juga memberikan perhatian terhadap kelangsungan hidup Ngesti Pandowo adalah Ir. Aris Krisdianto, M.T. Perkenalannya dengan Ngesti Pandowo terjadi ketika ia masih duduk di bangku Sekolah Dasar. Pada saat itu ia telah berlatih menari kepada seniman-seniman Ngesti Pandowo. Pada saat duduk di bangku Sekolah Menengah Pertama ia sering pentas pada perhelatan-perhelatan pesta perkawinan. Ia juga beberapa kali terlibat dalam pentas tari sebagai 
pembuka pertunjukan yang di kalangan anggota Ngesti Pandowo disebut dengan ekstra. Pengalaman-pengalaman beraktivitas seni bersama para anggota Ngesti Pandowo inilah yang kemudian mendorongnya untuk membantu Ngesti Pandowo ketika mengalami kekurangan pemain saat ia menjadi dosen dan Wakil Rektor II Universitas 17 Agustus 1945 Semarang. Perhatian itu ditunjukkan dengan pergelaran kolaborasi sivitas akademika Universitas 17 Agustus 1945 Semarang dengan Ngesti Pandowo pada 2015 dengan mengambil lakon Wiratha Parwa. Dalam pementasan rutin Ir. Aris Krisdianto, M.T. kadangkadang juga membantu Ngesti Pandowo apabila kekurangan pemain (Gambar 3). Ia berperan sebagai Werkudara. Ia juga pernah terlibat dalam pementasan Ngesti Pandowo di Taman Mini Indonesia Indah sebanyak tiga kali.

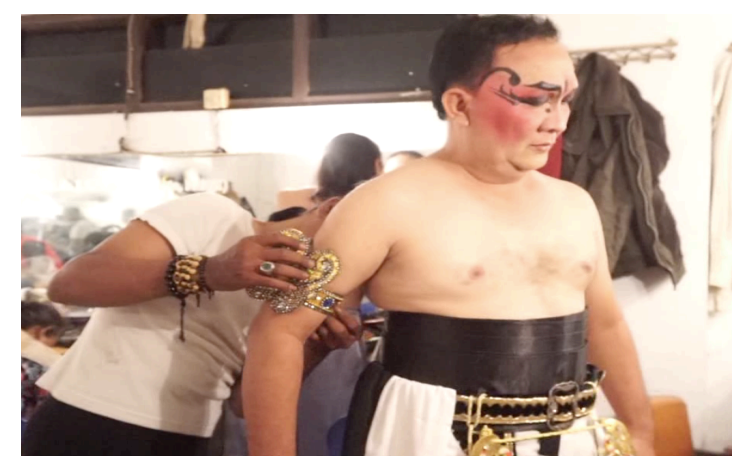

Gambar 3. Ir. Aris Krisdianto, M.T., sedang berhias di balik panggung untuk peran Werkudara dalam pergelaran wayang orang Ngesti Pandowo dengan cerita Sembadra Larung di Gedung Ki Nartosabdo Taman Budaya Raden Saleh Semarang pada 9 Februari 2019 (Sumber: Dokumentasi Peneliti).

Atas dasar keprihatinannya terhadap minat mahasiswa terhadap seni pertunjukan tradisi Jawa dan kurangnya pemain wanita pada Ngesti Pandowo, Ir. Aris Krisdianto, M.T. mengorganisasi mahasiswa Universitas 17 Agutus 1945 Semarang menyelenggarakan pelatihan tari yang dimaksudkan selain untuk memenuhi kebutuhan internal institusinya misalnya sebagai hiburan pada saat acara wisuda dan untuk membantu Ngesti Pandowo apabila memerlukan bantuan para pemain putri. Para mahasiswa itu dilatih ragam gerak tari dasar yang diperlukan untuk pertunjukan wayang orang (Wawancara dengan Ir. Aris Krisdianto, M.T., 13 Mei 2019). Ia juga memiliki komitmen untuk membantu Ngesti
Pandowo melalui penjalinan hubungan dengan berbagai pihak yang dapat membantu Ngesti Pandowo. Sebagai contoh, pada acara Forum Dialog Budaya dengan tema "Bergerak Bersama Membangun Seni Panggung Tradisi Wayang sebagai Identitas Kota Semarang" yang diselenggarakan oleh Komite Seni Budaya Nusantara Kota Semarang bekerja sama dengan Pemerintah Kota Semarang di Balai Kota Semarang pada 27 September 2019, Ir. Aris Krisdianto, M.T. juga mengusulkan agar para seniman Ngesti Pandowo diperjuangkan untuk dapat menjadi pegawai Pemerintah Kota Semarang.

Sosok lain dari perguruan tinggi yang berperan serta membantu Ngesti Pandowo adalah dr. Martha Ardiaria, M. Si. Med. Ia adalah seorang dokter yang sekaligus staf pengajar pada Program Studi Gizi, Fakultas Kedokteran Universitas Diponegoro. Kecintaannya pada seni tari klasik telah membawa wanita kelahiran 1981 ini untuk terjun dan berkontribusi aktif dalam pelestarian wayang orang Ngesti Pandowo.

Peran serta dr. Martha Ardiaria, M. Si. Med. di Ngesti Pandowo dimulai pada 2006, satu tahun setelah ia secara resmi diterima sebagai pegawai negeri sipil. Namun, ia telah terlibat dalam kesenian Jawa sejak masih duduk di bangku Sekolah Dasar. Saat itu, wanita yang menyelesaikan pendidikan dasar sampai dengan menengah atas di Ungaran ini aktif mewakili sekolahnya mengikuti berbagai kompetisi tari. Bakat dan hasil didikan pelatih baik di sekolah maupun lembaga kursus yang ia ikuti telah mendorongnya untuk semakin mendalami tari Jawa. Kegemarannya ini berlanjut saat ia melanjutkan studi kedokteran di Universitas Indonesia, Jakarta. Di kota ini ia bertemu dengan seniman tari Retno Maruti. Bersama dengan kelompok seni yang dipimpin oleh Retno Maruti, ia aktif mengikuti berbagai kegiatan event organizer dengan mementaskan berbagai macam jenis tari baik Jawa maupun Bali.

Berbagai pengalaman yang ia ikuti tidak menghilangkan impian dan obsesinya untuk menjadi penari utama di Ngesti Pandowo. Menurutnya, Ngesti Pandowo adalah ikon seni tradisi Semarang yang legendaris. Oleh karena itu, ia tidak berpikir panjang ketika Prof. Dr. dr. Edi 
Dharmana, M.Sc., Sp. Park., seniornya di Fakultas Kedokteran Universitas Diponegoro, mengajaknya turut serta dalam pementasan Ngesti Pandowo. Pada awal-awal pentas di Ngesti Pandowo, meskipun sebagai peran pembantu, dr. Martha Ardiaria, M. Si. Med., telah memerankan banyak sekali tokoh wayang (Gambar 4). Pada kesempatan-kesempatan itu pula, ia banyak menyerap berbagai pengetahuan dan teknik tari klasik dari para seniornya di Ngesti Pandowo. Meskipun demikian, ia mengakui bahwa tokohtokoh senior Ngesti Pandowo adalah tokoh-tokoh panggung. Artinya, mereka tidak dibekali dengan pengetahuan pengajaran sebagaimana guru tari, sehingga proses transfer of knowledge tidak berjalan secara runtut dan jelas. Beruntung, ia memiliki senior yang perhatian dan ngemong. Hal itu pula yang menjadi pendorong semangat baginya untuk terlibat aktif dalam setiap pementasan Ngesti Pandowo.

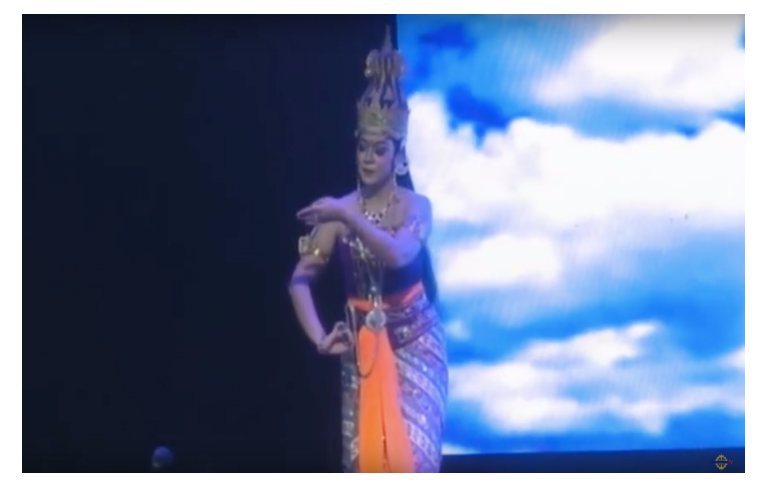

Gambar 4. dr. Martha Ardiaria, M. Si. Med. sedang memerankan Dewi Supraba dalam pergelaran Wayang Orang Specta 60 dengan lakon Semar mBangun Kahyangan pada 7 November 2017 (Sumber: Dokumentasi Peneliti).

Bagi dr. Martha Ardiaria, M. Si. Med., bergabung dengan Ngesti Pandowo telah mewujudkan impian masa kecilnya. Motivasi sang ayah bahwa "penari yang hebat adalah penari Ngesti Pandowo", telah menjadi semacam obsesi. Bakatnya yang semakin terasah telah mengantarnya untuk menjadi pemain utama dalam beberapa pementasan Ngesti Pandowo. Selama dua tahun berturut-turut sejak 2014 hingga 2015, ia tidak pernah absen satu kali pun dalam pementasan Ngesti Pandowo yang diselenggarakan pada setiap Sabtu malam. Ia juga aktif mengikuti pementasan kerja sama antara
Ngesti Pandowo dengan instansi lain. Dua yang utama adalah pementasan Wayang Orang Specta 60 (kerja sama dengan Universitas Diponegoro pada 7 November 2017) dan kethoprak (kerja sama dengan Bank Indonesia pada 8 Maret 2019). dr. Martha Ardiaria, M. Si. Med. mengakui bahwa kecintaanya pada seni Jawa merupakan dorongan dan obsesi pribadi. Keterlibatannya pada setiap pementasan Ngesti Pandowo, lebih sebagai wujud dari sikapnya yang tergila-gila pada seni Jawa. Namun, sosok dokter yang memiliki darah seni dari sang nenek yang merupakan penyanyi keroncong Radio Republik Indonesia Surakarta pada periode 1960-an itu, semakin menyadari bahwa kesenangannya pada seni Jawa adalah wujud kontribusinya bagi pelestarian seni tradisi Jawa. Ia menyadari pula bahwa pelestarian seni tradisi harus dilakukan secara serius dan tidak bisa dilakukan secara serampangan. Meskipun para pemain seperti dirinya bukan merupakan seniman "asli", tetapi jika sudah memutuskan untuk ikut pentas, maka harus dilakukan secara baik dan tidak asal-asalan. Idealisme ini pula yang menyebabkannya menolak tawaran pementasan jika merasa tidak menguasai sebuah peran karena latihan yang tidak cukup intensif (Wawancara dengan dr. Martha Ardiaria, M.Si. Med., 11 Mei 2019).

Para sivitas akademika Universitas Negeri Semarang juga turut berperan dalam memberi dukungan pemain untuk kelestarian Ngesti Pandowo. Sejak kegiatan para mahasiswa Program Studi Seni Drama, Tari, dan Musik serta Unit Kegiatan Mahasiswa Kesenian Jawa diperkenalkan kepada masyarakat, ada pihak yang menginginkan agar mereka membantu Ngesti Pandowo yang mengalami kekurangan pemain. Sebagian mahasiswa yang memiliki minat untuk mengembangkan kompetensi dan ketrampilannya dalam bidang tari dan wayang orang kemudian bergabung dengan Ngesti Pandowo. Dukungan para mahasiswa Universitas Negeri Semarang ini bersifat simbiosis mutualistis. Para mahasiswa mendapatkan wahana untuk berlatih tari dan menyelami dunia seni peran wayang orang serta bergaul dengan para "seniman alam". Mereka dapat menyerap pengetahuan tentang teori dan praktik tari, wayang orang, dan karawitan dari seniman Ngesti Pandowo. Di pihak lain Ngesti 
Pandowo mendapatkan tambahan pemain, khususnya untuk penari wanita. Sejak saat itu, ketika Ngesti Pandowo menggelar pentas rutin setiap malam Minggu atau pentas khusus untuk berbagai kepentingan misalnya ulang tahun organisasi tersebut dan pentas kolaborasi dengan berbagai lembaga juga didukung oleh para mahasiswa Universitas Negeri Semarang. Sampai saat ini telah terjalin hubungan yang baik antara Ngesti Pandowo dengan sivitas akademika Universitas Negeri Semarang (Wawancara dengan Dr. Widodo Brotosejati, S. Kar., M. Sn., 15 Agustus 2019).

\section{PEMANFAATAN TEKNOLOGI}

Kemajuan teknologi sering disebut sebagai salah satu faktor yang memengaruhi kehidupan seni pertunjukan tradisi. Soedarsono (2002), misalnya, menyatakan bahwa perkembangan teknologi media rekam semakin memudahkan orang untuk menikmati seni pertunjukan secara lebih praktis dan dengan biaya yang murah. Mereka juga tidak perlu menyediakan waktu khusus dan ongkos tambahan untuk menuju ke gedung pertunjukan. Di sisi lain, perkembangan teknologi media rekam telah menyebabkan kelompok-kelompok seni pertunjukan tradisi, terutama dalam kategori commercial support, mengalami kebangkrutan dan akhirnya bubar.

Dalam situasi ketika suatu kelompok seni pertunjukan tradisi yang dengan berbagai alasan tidak dapat lagi memunculkan kemasan pertunjukan yang kreatif dan inovatif, kemajuan teknologi menawarkan peluang untuk mengatasi masalah ini. Mereka dapat memanfaatkan teknologi untuk mendukung dan menambah daya tarik pementasan. Upaya itu telah dilakukan oleh Ngesti Pandowo. Paguyuban ini telah memanfaatkan laptop untuk membuat deskripsi singkat dalam bahasa Indonesia untuk setiap adegan yang dipentaskan di atas panggung, yang kemudian dipancarkan dengan menggunakan $L C D$ projector pada layar yang dipasang di sisi kanan dan kiri panggung. Pemanfaatan teknologi ini sangat membantu penonton untuk tetap dapat menikmati pertunjukan biarpun mereka kurang atau bahkan sama sekali tidak memahami dialog dalam bahasa Jawa yang dilakukan oleh tokoh- tokoh wayang di atas panggung. Kadang-kadang, pertunjukan wayang orang Ngesti Pandowo juga ditonton oleh penonton dari mancanegara. Mereka bisa jadi tidak memahami baik bahasa Indonesia maupun bahasa Jawa. Hal ini kiranya dapat dijadikan catatan kecil untuk melengkapi deskripsi yang ditayangkan pada layar dengan menggunakan bahasa internasional terutama bahasa Inggris. Berdasar pengamatan, pemanfaatan teknologi semacam ini juga telah dilakukan dalam pentas wayang orang Sriwedari Surakarta. Bedanya, Sriwedari hanya menggunakan satu buah layar yang dipasang di sisi kiri panggung.

Pemanfaatan teknologi untuk menambah daya tarik pentas wayang orang juga telah diperlihatkan oleh Ngesti Pandowo dengan dukungan Universitas Diponegoro yang dikemas sebagai Pentas Wayang Orang Specta 60 Guru Besar dengan lakon Semar Mbangun Kahyangan. Teknologi digunakan terutama untuk mendukung tata suara, tata cahaya, dan tata panggung. Dalam tata suara digunakan pengeras suara (microphone; mic) nirkabel kecil yang dapat ditempelkan pada tubuh anak wayang. Dengan mic semacam ini, yang didukung dengan speaker yang dipasang di sisi kanan dan kiri dinding gedung pertunjukan, dialog di atas panggung dapat terdengar secara jelas oleh penonton yang duduk di deret paling belakang. Dalam tata cahaya digunakan lampu beraneka warna yang dapat mendukung adegan yang sedang dimainkan. Selain itu juga digunakan lampu sorot dengan cahaya yang terfokus. Lampu ini digunakan untuk mendukung adegan tokoh Arjuna yang sedang melepaskan anak panah dari busurnya, yang dilakukan dari luar arena panggung. Anak panah yang telah dilepaskan terlihat melesat bercahaya karena telah diberi lilitan lampu. Sudah barang tentu, untuk mendukung adegan ini, cahaya di arena panggung dibuat redup, sedangkan lampu-lampu di bagian penonton dimatikan. Sementara itu, untuk mendukung tata panggung digunakan laptop dan $L E D$ untuk menanyangkan gambar-gambar sesuai dengan adegan yang sedang berlangsung di atas panggung, misalnya gambar pendopo, sawah, hutan, dan pertapaan. Ada pula gambar yang ditayangkan itu merupakan gambar hidup, misalnya awan yang berarak. 
Penggunaan teknologi semacam itu juga pernah dilakukan dalam pentas wayang orang Ngesti Pandowo bekerja sama dengan Universitas Katolik Soegijapranata. Dalam pentas ini digunakan layar $L E D$ besar sebagai pengganti geber, sehingga dekorasi panggung semakin menarik karena gambar yang ditampilkan dapat lebih bervariasi termasuk dengan menggunakan gambar hidup. Namun demikian, gagasan-gagasan yang berkaitan dengan teknologi akhirnya juga terhambat karena persoalan biaya dan sumber daya manusia. Ngesti Pandowo tidak memiliki dana yang cukup untuk membeli dan memanfaatkan LED untuk pementasannya. Persoalan lain yang juga menjadi kendala dalam pemanfaatan teknologi tersebut adalah sumber daya manusia yang mengoperasikannya. Ngesti Pandowo tidak memiliki sumber daya manusia yang memiliki kemampuan untuk menggunakan teknologi tersebut. Sampai dengan penulisan artikel ini Universitas Katolik Soegijapranata telah membuka jalinan kerja sama agar Badan Ekonomi Kreatif (Bekraf) dapat membantu merealisasikan gagasan-gagasan untuk memanfaatkan teknologi untuk melestarikan Ngesti Pandowo (Wawancara dengan Ir. Tjahjono Rahardjo, M.A., 21 April 2019). Penggunaan teknologi sebagaimana telah dikemukakan di atas dapat mendukung upaya untuk menciptakan kemasan pertunjukan wayang orang yang lebih atraktif. Pentas yang demikian itu juga lebih sesuai dengan kemajuan zaman.

Universitas Katolik Soegijapranata juga telah melangkah lebih jauh dalam upaya pemanfaatan teknologi untuk membantu pengembangan wayang orang Ngesti Pandowo. Hal itu dilakukan melalui pemanfaatan teknologi internet. Sejauh ini belum ada usaha khusus untuk menggunakan internet baik untuk mendiseminasikan pengetahuan mengenai wayang orang atau seni tradisi Jawa secara umum kepada khalayak. Di sisi lain, internet telah dimanfaatkan oleh banyak kalangan khususnya kaum muda yang pada umumnya telah menguasai kemampuan untuk menggunakan komputer. Oleh karena itu, tim peneliti dari Universitas Katolik Soegijapranata telah memelopori pemanfaatan internet untuk mendukung pengembangan dan pelestarian wayang orang Ngesti Pandowo, yang sekaligus juga untuk mempromosikan nilai-nilai tentang toleransi dan multikulturalisme dalam budaya Jawa, khususnya dalam seni pertunjukan tradisi wayang orang (Rahardjo, Sanjaya, dan Untari, 2018).

Universitas Katolik Soegijapranata juga telah memanfaatkan teknologi internet untuk memfasislitasi pelestarian dan pengembangan wayang orang Ngesti Pandowo sebagai bisnis hiburan. Seperti dikemukakan oleh Widiantoro, Sanjaya, Rahardjo, dan Winarno (2018), upaya itu dilakukan melalui pengembangan financial techonology yang memungkinkan transaksi keuangan, misalnya pembayaran tiket, dapat dilakukan dengan lebih praktis. Upaya yang lain adalah pengembangan sarana promosi dengan menggunakan media sosial berbasis internet, yaitu facebook, instagram, dan twitter. Penggunaan media komunikasi berbasis internet bukan hanya dapat memperkuat dan memperluas jaringan antara pengusaha dan pelanggan serta antaraorganisasi bisnis pertunjukan yang lebih efisien dan murah, tetapi juga dapat menciptakan imaji tentang wayang orang panggung atau seni pertunjukan tradisi pada umumnya yang selaras dengan kemajuan zaman dan "modern".

\section{SIMPULAN}

Berdasar pembahasan di atas dapat disimpulkan bahwa peranan perguruan tinggi dalam pengembangan wayang orang Ngesti Pandowo ditujukan pada empat aspek, yaitu peningkatan apresiasi masyarakat kampus khususnya kalangan mahasiswa melalui pentas kolaboratif, perbaikan manajemen organisasi melalui pembentukan Dewan Pembina Ngesti Pandowo dan melalui keterlibatan para akademisi dalam dewan itu, dukungan pemain untuk mengatasi kesulitan Ngesti Pandowo terkait dengan regenerasi yang tidak berjalan secara baik, dan pemanfaatan teknologi untuk peningkatan daya tarik pertunjukan wayang orang serta media promosi. Melalui berbagai kegiatan yang telah dilakukan itu, perguruan tinggi-perguruan tinggi di Kota Semarang telah memberikan kontribusi bagi upaya pelestarian wayang orang Ngesti Pandowo walaupun mereka sesungguhnya bukan lembaga pendidikan formal di bidang seni. 
Tentu harus diakui bahwa upaya itu belum cukup untuk dapat membawa kembali wayang orang Ngesti Pandowo seperti pada kejayaannya. Meskipun demikian, upaya itu telah memperlihatkan komitmen perguruan tinggi sebagai salah satu lembaga kebudayaan dalam mengembangkan dan melestarikan seni pertunjukan tradisi Jawa, khususnya wayang orang Ngesti Pandowo di Kota Semarang. Upaya itu juga telah diarahkan untuk mengembangkan wayang orang Ngesti Pandowo sebagai bagian dari industri kreatif. Sampai dengan penyelesaian tulisan ini perhatian perguruan tinggi di Semarang untuk pelestarian Ngesti Pandowo semakin lengkap dengan dukungan pengrawit mahasiswa Universitas Persatuan Guru Republik Indonesia Semarang dalam pergelaran dengan lakon Brandhal Saldja oleh Kawula Muda Ngesti Pandowo yang dihelat pada 9 November 2019. Dengan semakin banyaknya dukungan perguruan tinggi di Semarang dalam upaya pelestarian wayang orang Ngesti Pandowo telah memberi secercah harapan akan kelestarian paguyuban wayang orang tersebut.

\section{UCAPAN TERIMA KASIH}

Artikel ini merupakan luaran hasil penelitian yang dibiayai oleh Fakultas Ilmu Budaya Universitas Diponegoro berdasar Surat Perjanjian Pelaksanaan Kegiatan Penelitian Sumber Dana DIPA Fakultas Ilmu Budaya Universitas Diponegoro Tahun Anggaran 2019, No. 107938/UN7.5.6/HK/2019.

\section{REFERENSI}

Brandon, James R. (2003). Jejak-jejak Seni Pertunjukan di Asia Tenggara, terjemahan R.M. Soedarsono. Bandung: Pusat Penelitian dan Pengembangan Pendidikan Seni Universitas Pendidikan Indonesia.

Davis, Cullom et al. (1977). Oral History: From the Tape to Type. Chicago: American Library Association.

Garraghan, Gilbert J. (1959). A Guide to Historical Method. Fordham University Press.
Kayam, Umar (1982). "Ngesti Pandowo: Suatu Persoalan Kitsch di Negara Berkembang”, Kompas, 20 Oktober 1982.

Kayam, Umar (1991). "Ngesti Pandowo: Suatu Persoalan Kitsch di Negara Berkembang”, dalam Edi Sedyawati \& Sapardi Djoko Damono. 1991. Seni dalam Masyarakat Indonesia: Bunga Rampai. Jakarta: PT Gramedia Pustaka Utama.

Kayam, Umar (2000). “Transformasi Budaya Kita”, Pidato Pengukuhan Jabatan Guru Besar pada Fakultas Sastra Universitas Gadjah Mada pada 19 Mei 1989, dalam Senat Universitas Gadjah Mada, Pidato Pengukuhan Guru Besar Universitas Gadjah Mada: Ilmu-Ilmu Humaniora, 1949-1999. Yogyakarta: Gadjah Mada Univerity Press.

Koentjaranningrat (1984). Kebudayaan Jawa. Jakarta: Balai Pustaka.

Mumpuni, Heni Sulistyo (1986). "Pertumbuhan Perkumpulan Kesenian Ngesti Pandowo Semarang Tahun 1937-1983”. Skripsi Jurusan Sejarah Fakultas Sastra Universitas Diponegoro.

Panitia Pekan Pameran Ekonomi dan Kebudayaan Kodya Semarang (1968). Mengenal Kotamadya Semarang. Semarang: Pemerintah Kodya Semarang.

Puguh, Dhanang Respati dan Endang Susilowati (2018). "Globalisasi Seni Pertunjukan Wayang Kulit Purwa”. Semarang: Fakultas Ilmu Budaya Universitas Diponegoro.

Puguh, Dhanang Respati dan Mahendra P. Utama (2018). "Peranan Pemerintah dalam Pengembangan Wayang Orang Panggung". Jurnal Sejarah Citra Lekha, Vol. 3 (2): 133153.

Puguh, Dhanang Respati, Rabith Jihan Amaruli, dan Mahendra Pudji Utama (2017). “Teater Kitsch Ngesti Pandowo di Kota Semarang Tahun 1950-an-1970-an”. Mozaik Humaniora, Vol. 17 (1): 1-25.

Puguh, Dhanang Respati, Rabith Jihan Amaruli, Mahendra Pudji Utama (2016). "Model Pengembangan Manajemen Seni Pertunjukan Tradisi untuk Melestarikan Wayang Orang Ngesti Pandowo Guna Mendukung Pariwisata Budaya di Kota 
Semarang”. Laporan Riset Pengembangan dan Penerapan Universitas Diponegoro.

Puguh, Dhanang Respati, Rabith Jihan Amaruli, Mahendra Pudji Utama (2017). "Model Pengembangan Manajemen Seni Pertunjukan Tradisi untuk Melestarikan Wayang Orang Ngesti Pandowo Guna Mendukung Pariwisata Budaya di Kota Semarang”. Laporan Riset Pengembangan dan Penerapan Universitas Diponegoro.

Puguh, Dhanang Respati, Rabith Jihan Amaruli, Mahendra Pudji Utama (2018). "Model Pengembangan Manajemen Seni Pertunjukan Tradisi untuk Melestarikan Wayang Orang Ngesti Pandowo Guna Mendukung Pariwisata Budaya di Kota Semarang”. Laporan Riset Pengembangan dan Penerapan Universitas Diponegoro.

Puguh, Dhanang Respati (2015). "Mengagungkan

Kembali Seni Pertunjukan Tradisi Keraton: Politik Kebudayaan Jawa Surakarta 1950an-1990-an”. Disertasi pada Program Pascasarjana Fakultas Ilmu Budaya Universitas Gadjah Mada.

Rahardjo, Tjahjono, Ridwan Sanjaya, dan Rustina Untari (2018). "Wayang, Tolerance and the Internet". International Journal of Education and Applied Research, Vol. 2, Issue 2, July-December.

Rinardi, Haryono, Dhanang Respati Puguh, Siti Maziyah (2002). "Perkumpulan Wayang Orang Ngesti Pandowo (1937-2001): Studi tentang Manajemen Seni Pertunjukan. Laporan Penelitian Dibiayai Dana DIK Rutin Universitas Diponegoro.

Sevilla, Consuelo G., et al. (1993). Pengantar Metode Penelitian. Jakarta: Penerbit Universitas Indonesia.

Soedarsono (1999). Metodologi Penelitian Seni Pertunjukan dan Seni Rupa. Bandung: Masyarakat Seni Pertunjukan Indonesia.

Soedarsono (2002). Seni Pertunjukan Indonesia di Era Globalisasi. Yogyakarta: Gadjah Mada University Press.

Sumarsam (2018). Memaknai Wayang dan Gamelan: Temu Silang Jawa, Islam, dan Global, terjemahan Tim LIKE Indonesia. Yogyakarta: Penerbit Gading.
Surjodiningrat, Wasisto (1985). "Studi Kesenian Jawa di Jepang", dalam Soedarsono, Retna Astuti, dan I.W. Pantja Sunjata (Penyunting), Studi Gamelan Jawa di Luar Negeri. Yogyakarta: Proyek Penelitian dan Pengkajian Kebudayaan Nusantara (Javanologi) Direktorat Jenderal Kebudayaan Departemen Pendidikan dan Kebudayaan, hlm. 35-52.

Susilo, Hardjo (1985). "Sumbangan Para Sarjana dalam Pengembangan Karawitan di Amerika Serikat", Soedarsono, Retna Astuti, dan I.W. Pantja Sunjata (Penyunting). Studi Gamelan Jawa di Luar Negeri. Yogyakarta: Proyek Penelitian dan Pengkajian Kebudayaan Nusantara (Javanologi) Direktorat Jenderal Kebudayaan Departemen Pendidikan dan Kebudayaan, hlm. 13-34.

Sutton, R. Anderson (1985). "Studi Kesenian Jawa di Amerika Serikat", dalam Soedarsono, Retna Astuti, dan I.W. Pantja Sunjata (Penyunting), Studi Gamelan Jawa di Luar Negeri. Yogyakarta: Proyek Penelitian dan Pengkajian Kebudayaan Nusantara (Javanologi) Direktorat Jenderal Kebudayaan Departemen Pendidikan dan Kebudayaan, hlm. 1-12.

Thompson, Paul (1978). The Voice of the Past: Oral History. London: Oxford University

Widiantoro, Albertur Dwiyoga, Ridwan Sanjaya, Tjahyono Rahardjo, dan A. Rachmat Djati Winarno (2018). "Integration of Internet Technology to Support the Wayang Orang Ngesti Pandawa Business", E3S Web of Conferences 73, 13013, ICENIS 2018, hlm. 1-5.

Widiantoro, Albertus Dwiyoga, Ridwan Sanjaya, Tjahjono Rahardjo, dan A. Rachmat Djati Winarno (2018). "Increase Student Awareness of People's Cultural Heritage Using Internet Technology". The Fourteenth International Conference on eLearning for Knowledge-Based Society, Thailand, 18 March 2018, hlm. 101-105.

Widyastutieningrum, Sri Rochana (2018). "Reviving Wayang Orang Sriwedari in Surakarta: Tourism-Oriented Performance" Asian Theatre Journal, Vol. 35 (1): 100-111. 
"WO Ngesti Pandowo Terpaksa Jual Gamelan", Suara Merdeka, 6 Oktober 1982.

Yampolsky, Philip (1987). Lokananta A Discography of The National Recording Company of Indonesia 1957-1985. Madison, Wisconsin: Center for Southeast Asian Studies University of Winconsin.

Yampolsky, Philip (2001). "Can the Traditional Arts Survive, and Should They?" Indonesia 71 (April): 175-185.

\section{DAFTAR INFORMAN}

dr. Martha Ardiaria, M.Si. Med., Dosen Program Studi Gizi Fakultas Kedokteran Universitas Diponegoro.

Dr. Widodo Brotosejati, S. Kar., M.Sn., Dosen Jurusan Sendratasik Fakultas Bahasa dan Seni Universitas Negeri Semarang.

Ir. Aris Krisdianto, M.T., Dosen Fakultas Teknik Universitas 17 Agustus 1945 Semarang.

Ir. Tjahjono Rahardjo, M.A. Dosen Universitas Katholik Soegijapranata Semarang.

Prof. Dr. dr. Edi Dharmana, M. Sc., Sp. Park., Guru Besar Emeritus Fakultas Kedokteran Universitas Diponegoro. 